\title{
ANALISA WAKTU PEMUTUSAN KRITIS SUATU SISTEM KELISTRIKAN
}

\author{
Nathaniel L Bijang ${ }^{1)}$ \\ ${ }^{1)}$ Program Studi Teknik Elektro Politeknik Negeri Manado \\ e-mail: nbijang@yahoo.com
}

\begin{abstract}
ABSTRAK
Kestabilan adalah kemampuan mesin sinkron dari sistem tenaga listrik untuk mencapai kondisi stabil pada kondisi operasi baru yang sama atau identik dengan kondisi sebelum terjadi gangguan. Umumnya analisa kestabilan terbagi dalam dua kategori yaitu kestabilan steady state yaitu analisa sistem untuk kembali ke kondisi stabil setelah mengalami gangguan kecil dan kestabilan transient yaitu analisa sistem untuk kembali ke kondisi normal/stabil setelah mengalami gangguan besar. Studi/analisa stabilitas sangat diperlukan saat perencanaan pembangkit dan transmisi. Analisa/studi stabilitas sistem tenaga listrik membantu untuk menentukan setting waktu on/off relai proteksi, waktu pemutusan kritis circuit breaker, level tegangan dan kapasitas transfer diantara sistem-sistem.
\end{abstract}

Kata kunci: Mesin sinkron, stabilitas, waktu pemutusan kritis

\section{CRITICAL CLEARING TIME ANALYSIS ELECTRICAL POWER SYSTEM}

\begin{abstract}
The stability problem is concerned with the behavior of the synchronous machines after a disturbance. Transient stability studies are needed to ensure the system can withstand the transient condition following a major disturbance. Frequently,such studies are conducted when new generating and transmitting facilities are planned. The studies are helpful in determining such things as the nature of the relaying system needed, critical clearing time of circuit breakers, voltage level of, and transfer capability between systems.
\end{abstract}

Keywords: Synchronous machine, stability, critical clearing time

\section{PENDAHULUAN}

Dalam pengoperasian suatu sistem tenaga listrik maka pada setiap saat akan selalu terjadi perubahan kapasitas dan letak beban dalam sistem. Perubahan tersebut mengharuskan setiap pembangkit menyesuaikan daya keluarannya melalui kendali governor maupun eksitasi mengikuti perubahan beban sistem. Jika hal ini tidak dilakukan maka akan menyebabkan keseimbangan daya dalam sistem terganggu dan efisiensi pengoperasian sistem menurun menyebabkan kinerja sistem memburuk. Kecepatan pembangkit memberi reaksi terhadap perubahan yang terjadi dalam sistem menjadi faktor penentu kestabilan sistem.

Kestabilan mesin pembangkit sangat tergantung pada kemampuan sistem kendalinya. Sistem kendali yang andal jika mampu mengendalikan mesin tetap beroperasi normal mengikuti perubahan- perubahan yang terjadi dalam sistem. Jika semua mesin tetap beroperasi dalam kondisi normal meskipun ada gangguan, maka sistem tersebut akan benar-benar stabil.

Stabilitas sistem tenaga listrik merupakan karakteristik sistem tenaga yang memungkinkan mesin bergerak serempak dalam sistem pada operasi normal dan dapat kembali dalam keadaan seimbang setelah terjadi gangguan. Secara umum permasalahan stabilitas sistem tenaga listrik terkait dengan kestabilan sudut rotor dan kestabilan tegangan. Klasifikasi ini berdasarkan rentang waktu dan mekanisme terjadinya ketidakstabilan. Kestabilan sudut rotor diklasifikasikan menjadi small signal stability dan transient stability. Small signal stability adalah kestabilan sistem untuk gangguan-gangguan kecil dalam bentuk osilasi elektromekanik yang tak teredam, sedangkan transient stability dikarenakan kurang sinkronnya torsi dan diawali dengan 
gangguan-gangguan besar. Masalah kestabilan biasanya diklasifikasikan menjadi tiga tipe bergantung pada sifat alami dan magnitude gangguan, yaitu : stabilitas steady state, stabilitas transient, dan stabilitas dinamis.

\section{TINJAUAN PUSTAKA}

\section{Persamaan Ayunan (Swing Equation)}

Menurut Nadjamuddin (2012) dan Saadat (1999), persamaan yang mengatur gerakan rotor suatu mesin sinkron didasarkan pada prinsip dasar dalam dinamika yang menyatakan bahwa momen putar percepatan merupakan hasil kali dari momen kelembaman rotor dan percepatan sudutnya. Untuk generator sinkron persamaan ini dapat ditulis dalam bentuk :

$$
J \frac{d^{2} \theta_{m}}{d t^{2}}=T_{a}=T_{m}-T_{e}
$$

Dengan $J$ adalah momen kelembaman total dari massa rotor dalam satuan $\mathrm{kg}-\mathrm{m}^{2}$, $\theta_{m}$ adalah sudut pergeseran rotor terhadap suatu sumbu yang diam dalam satuan radian, $T_{a}$ adalah momen putar percepatan bersih dalam satuan Newton-meter, $T_{m}$ adalah momen putar mekanis dalam satuan Newton Meter dan $T_{e}$ adalah momen putar elektromagnetis dalam satuan Newton-meter. Jika generator sinkron membangkitkan torsi elektromagnetis dalam keadaan berputar pada kecepatan sinkron $\omega_{s m}$ maka :

$$
T_{m}=T_{e}
$$

Jika terjadi gangguan akan menghasilkan suatu percepatan $\left(T_{m}>T_{e}\right)$ atau perlambatan $\left(T_{m}<T_{e}\right)$ dengan,

$$
T_{a}=T_{m}-T_{e}
$$

Untuk menentukan penyelesaian persamaan ayunan pada operasi steady state dimana $P_{e}=P_{m}$ dan sudut daya mula-mula diberikan oleh :

$\delta_{0}=\operatorname{Sin}^{-1}\left[\frac{P_{m}}{P 1_{\text {mak }}}\right]$ dengan $P 1_{\text {mak }}=\frac{\left|E^{\prime}\right| \cdot|V|}{X_{1}}$ dan $X_{1}$ adalah reaktansi transfer sebelum gangguan, Rotor berputar pada kecepatan sinkron dan kemudian kecepatan putar berubah menjadi nol, sehingga : $\omega_{0}=0$.

Gangguan tiga fasa terjadi pada saluran transmisi sehingga persamaan sudut daya menjadi : $P 2_{\text {mak }}=\frac{\left|E^{\prime}\right| \cdot|V|}{X_{2}}$ dengan $X_{2}$ adalah reaktansi transfer selama gangguan. Dengan demikian persamaan ayunan yang diberikan oleh persamaan sebagai berikut: $\frac{d^{2} \delta}{d t^{2}}=\frac{\pi \cdot f_{0}}{H}\left(P_{m}-P_{2 m a k} \sin \delta\right)=\frac{\pi f_{0}}{H} P_{a}$ Persamaan ayunan di atas ditransformasikan ke dalam bentuk pernyataan variable sebagai berikut :

$\frac{d \delta}{d t}=\omega \quad$ dan $\quad \frac{d \omega}{d t}=\frac{\pi \cdot f_{0}}{H} P_{a}$ yang akan di aplikasikan ke metode Runge Kutta Orde-4.

Untuk menentukan harga $\delta$ dan $\omega$ dengan penyelesaian metode Runge-Kutta orde 4 , terlebih dahulu tentukan harga-harga $k_{1}, k_{2}$, $k_{3}, k_{4}, I_{1}, I_{2}, I_{3}$, dan $I_{4}$, yaitu sebagi berikut :

$k_{1}=f\left(\delta_{i} . \omega_{i}\right) \Delta t=\omega_{i} \Delta t$

$I_{1}=g\left(\delta_{i}, \omega_{i}\right) \Delta t=\frac{\pi f}{H}\left(P_{m}-P_{e}\right) \Delta t$

$k_{2}=f\left(\delta_{i}+\frac{1}{2} k_{1}, \omega_{i}+\frac{1}{2} I_{1}\right) \Delta t=\left(\omega_{i}+\frac{1}{2} I_{1}\right) \Delta t$

$I_{2}=g\left(\delta_{i}+\frac{1}{2} k_{1}, \omega_{i}+\frac{1}{2} I_{1}\right) \Delta t$

$=\frac{\pi f}{H}\left(P_{m}-P_{e} \sin \left(\delta_{i}+\frac{1}{2} k_{1}\right)\right) \Delta t$

$k_{3}=f\left(\delta_{i}+\frac{1}{2} k_{2}, \omega_{i}+\frac{1}{2} I_{2}\right) \Delta t$

$=\left(\omega_{i}+\frac{1}{2} I_{2}\right) \Delta t$

$I_{3}=g\left(\delta_{i}+\frac{1}{2} k_{2}, \omega_{i}+\frac{1}{2} I_{2}\right) \Delta t$

$=\frac{\pi f}{H}\left(P_{m}-P_{e} \sin \left(\delta_{i}+\frac{1}{2} k_{2}\right)\right) \Delta t$

$k_{4}=f\left(\delta_{i}+k_{3}, \omega_{i}+I_{3}\right) \Delta t=\left(\omega_{i}+I_{3}\right) \Delta t$

$I_{4}=g\left(\delta_{i}+k_{3}, \omega_{i}+I_{3}\right) \Delta t$

$$
=\frac{\pi f}{H}\left(P_{m}-P_{e} \sin \left(\delta_{i}+k_{3}\right)\right) \Delta t
$$

Selanjutnya harga harga $\delta$ dan $\omega$ dapat ditentukan dengan menggunakan persamaan sebagai berikut :

$$
\begin{aligned}
& \delta_{i+1}=\delta_{i}+\frac{1}{6}\left(k_{1}+2 k_{2}+2 k_{3}+k_{4}\right) \\
& \omega_{i+1}=\omega_{i}+\frac{1}{6}\left(I_{1}+2 I_{2}+2 I_{3}+I_{4}\right) .
\end{aligned}
$$

\section{Sistem Mesin Majemuk}

Menurut Edminister (1972) dan Murty (1984), persamaan mesin majemuk dapat ditulis sama dengan sistem satu mesin yang dihubungkan dengan infinite bus. Untuk mengurangi kerumitan dalam menganalisis stabilitas transient dapat dibuat penyederhanaan dengan asumsi-asumsi sebagai berikut :

a. Setiap mesin sinkron direpresentasikan sebagai sumber tegangan konstan disamping reaktansi transient sumbu langsung. Representasi ini mengabaikan 
efek salient/kutub tonjol dan mengasumsikan fluks bocor yang konstan.

b. Aksi governor diabaikan dan daya masukan diasumsikan selalu konstan selama keseluruhan periode simulasi.

c. Semua beban diubah menjadi admitansi ke ground dan diasumsikan konstan.

d. Redaman atau daya asinkron diabaikan.

e. Sudut mekanik rotor setiap mesin bertepatan dengan sudut tegangan disamping reaktansi mesin.

Langkah pertama dalam analisis stabilitas transient adalah mula-mula menyelesaikan aliran daya dan menentukan magnitude tegangan bus mula-mula serta sudut fasa. Arus mesin sebelum gangguan dihitung dengan persamaan :

$$
I_{i}=\frac{s_{i}^{*}}{V_{i}^{*}}=\frac{P_{i}-j Q_{i}}{V_{i}^{*}} \quad, i=1,2, \ldots, m
$$

Dengan $m$ adalah jumlah generator, $V_{i}$ adalah tegangan terminal generator ke-i. $P_{i}$ dan $Q_{i}$ adalah daya nyata dan daya reaktif generator. Semua harga yang diketahui ditentukan dari magnitude tegangan bus mula-mula yang didapat dari penyelesaian aliran daya. Resistansi jangkar generator pada umumnya diabaikan dan tegangan disamping reaktansi transient diperoleh dari persamaan berikut :

$$
E_{i}=V_{i}+j X_{d}^{\prime} I_{i}
$$

Selanjutnya semua beban diubah menjadi admitansi ekivalen dengan menggunakan hubungan :

$Y_{L}=\frac{S_{L}^{*}}{|V L|^{2}}=\frac{P_{i}-j Q_{i}}{|V L|^{2}} \quad$ dengan $\quad P_{L}+j Q_{L}$ adalah beban dan $\left|V_{L}\right|$ adalah besar tegangan bus. Tegangan yang meliputi disamping reaktansi transient pada sistem jaringan $\mathrm{m}$ bus ditambah dengan $n$ bus. Semua beban jaringan ekivalenini diubah menjadi admitansi. Titik $n+1, n+2, \ldots, n+m$ adalah bus internal mesin, yaitu bus disamping reaktansi transient. Persamaan tegangan titik simpul dengan titik nol sebagai referensi untuk jaringan ini yang diberikan oleh persamaan berikut ini : $I_{b u s}=Y_{b u s} . V_{b u s}$. Dengan $I_{b u s}$ adalah vektor arus yang disuntikkan pada bus dan $V_{\text {bus }}$ adalah vektor tegangan bus diukur dari titik referensi. Elemen diagonal dari matriks admitansi bus adalah jumlah admitansi yang terhubung dengan bus tersebut, dan elemen diagonal ini bertanda negatif.

Tidak ada arus yang masuk atau meninggalkan bus beban. Arus dalam baris ke- $n$ adalah nol. Arus generator dinyatakan dengan vektor $I_{m}$ dan tegangan generator dan beban dinyatakan berturut-turut oleh vektor $E_{m}$ dan $V_{n}$ persamaan dalam bentuk matriks adalah sbagai berikut :

$\left[\begin{array}{c}0 \\ I_{m}\end{array}\right]=\left[\begin{array}{cc}Y_{n n} & Y_{n m} \\ Y_{n m}^{t} & Y_{m m}\end{array}\right]\left[\begin{array}{c}V_{n} \\ E_{m}^{\prime}\end{array}\right]$ atau

$0=Y_{n n} V_{n}+Y_{n m} E_{m}^{\prime}$

$I_{m}=Y_{n m}^{t} V_{n}+Y_{m n} E_{m}^{\prime}$

Dari persamaan sebelumnya didapat harga $V_{n}$ sebagi berikut: $V_{n}=-Y_{n n}^{-1} Y_{n m} E_{m}^{\prime}$

Subsitusi persamaan diatas kepersamaan $I_{m}=Y_{n m}^{t} V_{n}+Y_{m n} E_{m}^{\prime}$, sehingga didapatkan $I_{m}=\left[Y_{m m}-Y_{n m}^{t} Y_{n n}^{-t} Y_{n m}\right] E_{m}^{\prime}=Y_{b u s}^{\text {red }} E_{m}^{\prime}$ Sehingga dari persamaan ini didapatkan matriks admitansi reduksi bus sebagai berikut:

$Y_{b u s}^{r e d}=Y_{m m}-Y_{n m}^{t} Y_{n n}^{-t} Y_{n m} \quad$ matriks admitansi bus pada persamaan tersebut adalah berdimensi $(m x M)$, dengan $m$ adalah jumlah generator.

Daya listrik keluaran setiap mesin dinyatakan dalam bentuk tegangan internal mesin dengan persamaan sebagai berikut:

$S_{e i}^{*}=E_{i}^{*} I_{i}$ atau $P_{e i}=\mathfrak{R}\left\lceil E_{i}^{*} I_{i}\right\rceil$ dengan $I_{i}=\sum_{j=i}^{m} E_{j}^{\prime} Y_{i j} \quad$ Tegangan dan admitansi dinyatakan dalam bentuk polar, yaitu:

$E_{i}^{\prime}=\left|E_{i}^{\prime}\right| \angle \delta_{i}$ dan $Y_{i j}=\left|Y_{i j}\right| \angle \theta_{i}$, dan subsitusi harga $I i$ dari persamaan

$I_{i}=\sum_{j=i}^{m} E_{j}^{\prime} Y_{i j} \quad$ ke persamaan

$P_{e i}=\Re\left[E_{i}^{*} I_{i}\right\rceil$ menghasilkan persamaan :

$P_{e i}=\sum_{j=i}^{m}\left|E_{i}^{\prime}\right|\left|E_{j}^{\prime}\right|\left|Y_{i j}\right| \cos \left(\theta_{i j}-\delta_{i}+\delta_{j}\right)$.

\section{Stabilitas Transient Mesin Majemuk}

Menurut Grainger, Stevenson dan William (1994) serta Wood dan Wollendberg (1984), studi stabilitas transient klasik didasarkan pada aplikasi gangguan tiga fasa. Gangguan tiga fasa permanen pada bus $k$ dalam jaringan menghasilkan $V k=0$. Hal ini ditunjukkan oleh perpindahan baris dan kolom ke- $k$ dari matriks admitansi bus sebelum gangguan. Matriks admitansi bus baru adalah dikurangi oleh oleh penghilangan semua titik (node) kecuali titik ionternal generator. Tegangan eksitasi generator selama gangguan dan titik gangguan diasumsikan konstan. Daya listrik dari generator ke- $I$ dalam bentuk matriks admitansi bus baru yang direduksi diperoleh dari persamaan 
$P_{e i}=\sum_{j=i}^{m}\left|E_{i}^{\prime}\right|\left|E_{j}^{\prime}\right|\left|Y_{i j}\right| \cos \left(\theta_{i j}-\delta_{i}+\delta_{j}\right)$. Persamaan ayunan dengan redaman diabaikan, sebagaimana diberikan oleh persamaan sebelumnya. Untuk itu persamaan ayunan mesin I menjadi :

$$
\begin{aligned}
& \frac{H}{\pi \cdot f_{0}} \frac{d^{2} \delta_{i}}{d t^{2}}=P_{m i}- \\
& \sum_{j=i}^{m}\left|E_{i}^{\prime}\right|\left|E_{j}^{\prime}\right|\left|Y_{i j}\right| \cos \left(\theta_{i j}-\delta_{i}+\delta_{j}\right)
\end{aligned}
$$

Dengan $Y_{i j}$ adalah elemen-elemen matriks admitansi bus gangguan yang direduksi, dan $H_{i}$ adalah konstanta inersia mesin $i$ yang dinyatakan dalam MVA pada dasar $S_{B}$. Jika $H_{G i}$ adalah konstanta inersia dan mesin $i$ dinyatakan dalam MVA pada rating $S_{G i}$, maka $H_{i}$ diberikan dalam : $H_{i}=\frac{S_{G i}}{S_{B}} H_{G i}$

Daya listrik diperlihatkan generator ke-i oleh $P_{e}^{f}$ dan perubahan persamaan

$\frac{H}{\pi . f_{0}} \frac{d^{2} \delta_{i}}{d t^{2}}=P_{m i}-$

$\sum_{j=i}^{m}\left|E_{i}^{\prime}\right|\left|E_{j}^{\prime}\right|\left|Y_{i j}\right| \cos \left(\theta_{i j}-\delta_{i}+\delta_{j}\right)$

ke dalam model variable keadaan dinyatakan dengan : $\frac{d \delta_{i}}{d t}=\omega_{i} \quad i=1,2, \ldots, m$

$$
\frac{d \omega_{i}}{d t}=\frac{\pi \cdot f_{0}}{H_{i}} \cdot\left(P_{m}-P_{e}^{f}\right) \text {. }
$$

\section{HASIL DAN PEMBAHASAN}

\section{Sistem Kelistrikan Yang Ditinjau}

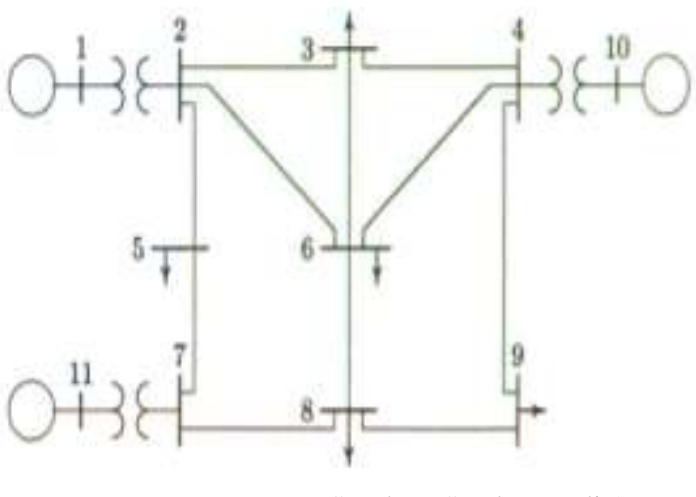

Sumber: Saadat, Hadi,1999

Gambar 1. Sistem Kelistrikan yang akan ditinjau/dianalisis

Bus_1 sebagai Slack bus V1 $=1.04 \angle 0^{0}$; Base

\begin{tabular}{|c|c|c|c|c|c|c|c|c|c|}
\hline \multicolumn{3}{|c|}{ LOAD } & \multicolumn{4}{|c|}{ Generator Schedule } & \multicolumn{3}{|c|}{ Data Mesin } \\
\hline \multirow{2}{*}{$\begin{array}{l}\text { No. } \\
\text { Bus }\end{array}$} & \multirow{2}{*}{ MW } & \multirow{2}{*}{ Mvar } & \multirow{2}{*}{$\begin{array}{c}\text { Voltage } \\
\text { Mag. }\end{array}$} & \multirow{2}{*}{$\begin{array}{c}\text { Generator } \\
\text { MW }\end{array}$} & \multicolumn{2}{|c|}{ Mvar Limits } & \multirow{2}{*}{$\mathrm{Ra}$} & \multirow{2}{*}{$X^{\prime} d$} & \multirow{2}{*}{$\mathrm{H}$} \\
\hline & & & & & Min & Max & & & \\
\hline 1 & 0.0 & 0.0 & 1.040 & 0.0 & 0.0 & 0.0 & 0.0 & 0.20 & 12 \\
\hline 2 & 0.0 & 0.0 & 0.0 & 0.0 & 0.0 & 0.0 & 0.0 & 0.0 & 0.0 \\
\hline 3 & 150 & 120 & 0.0 & 0.0 & 0.0 & 0.0 & 0.0 & 0.0 & 0.0 \\
\hline 4 & 0.0 & 0.0 & 0.0 & 0.0 & 0.0 & 0.0 & 0.0 & 0.0 & 0.0 \\
\hline 5 & 120 & 60 & 0.0 & 0.0 & 0.0 & 0.0 & 0.0 & 0.0 & 0.0 \\
\hline 6 & 140 & 90 & 0.0 & 0.0 & 0.0 & 0.0 & 0.0 & 0.0 & 0.0 \\
\hline 7 & 0.0 & 0.0 & 0.0 & 0.0 & 0.0 & 0.0 & 0.0 & 0.0 & 0.0 \\
\hline 8 & 110 & 90 & 0.0 & 0.0 & 0.0 & 0.0 & 0.0 & 0.0 & 0.0 \\
\hline 9 & 80 & 50 & 0.0 & 0.0 & 0.0 & 0.0 & 0.0 & 0.0 & 0.0 \\
\hline 10 & 0.0 & 0.0 & 1.035 & 200 & 0.0 & 180 & 0.0 & 0.15 & 10 \\
\hline 11 & 0.0 & 0.0 & 1.030 & 160 & 0.0 & 120 & 0.0 & 0.25 & 9 \\
\hline
\end{tabular}
100 MVA.

Tabel 1 Data Beban, Mesin dan Schedule Generation

Suatu gangguan tiga fasa terjadi pada line/saluran yang menghubungkan antara 2 buah bus dan pemutusan secara simultaneous opening of breakers pada kedua ujung line/saluran dimana gangguan tiga fasa terjadi.
Untuk

menentukan

dan mensimulasikan waktu pemutusan kritis dari pemutusan akibat gangguan tiga fasa pada saluran yang menghubungkan antar dua bus yang mengalami gangguan (fault) maka berdasarkan data disusunlah suatu program berbasis Matlab (Lampiran). 
Hasil simulasi pemutusan gangguan pada saluran/line yang mengalami gangguan tiga fasa, dalam hal ini dilakukan simulasi fault cleared pada tiga lokasi gangguan yang berbeda dan hasilnya adalah sebagai berikut :

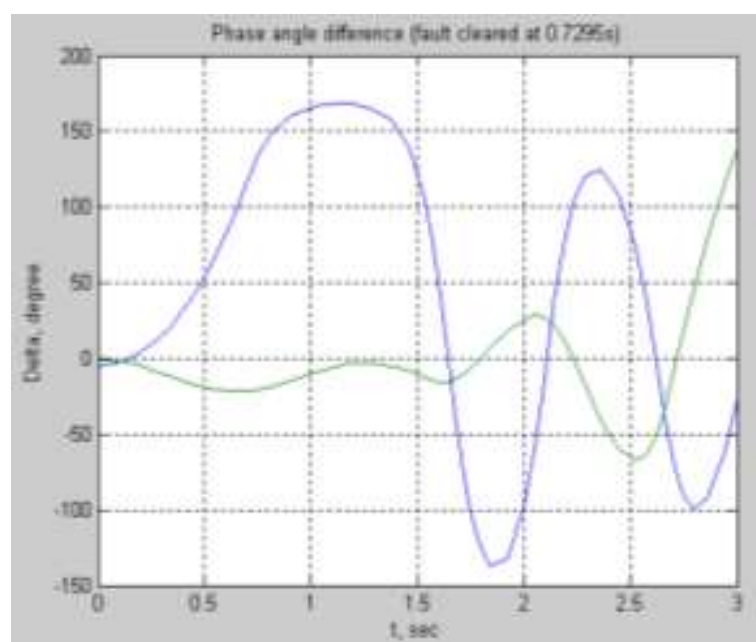

Gambar 2 Pemutusan kritis pada line 4_9 dekat bus 4 ( fault cleared at $0,7295 \mathrm{sec}$ )

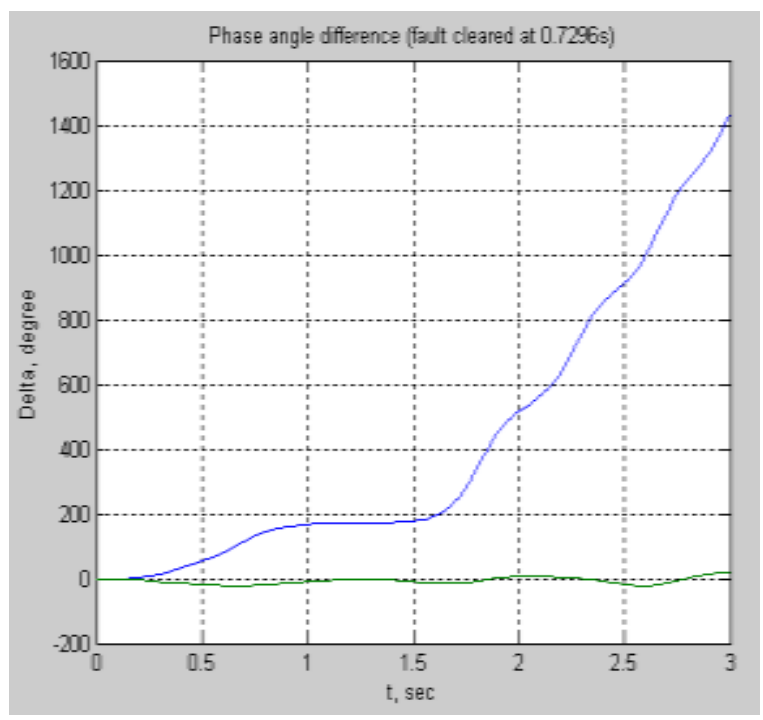

Gambar 3 Gangguan pada line 4_9 (fault cleared at 0,7296sec)

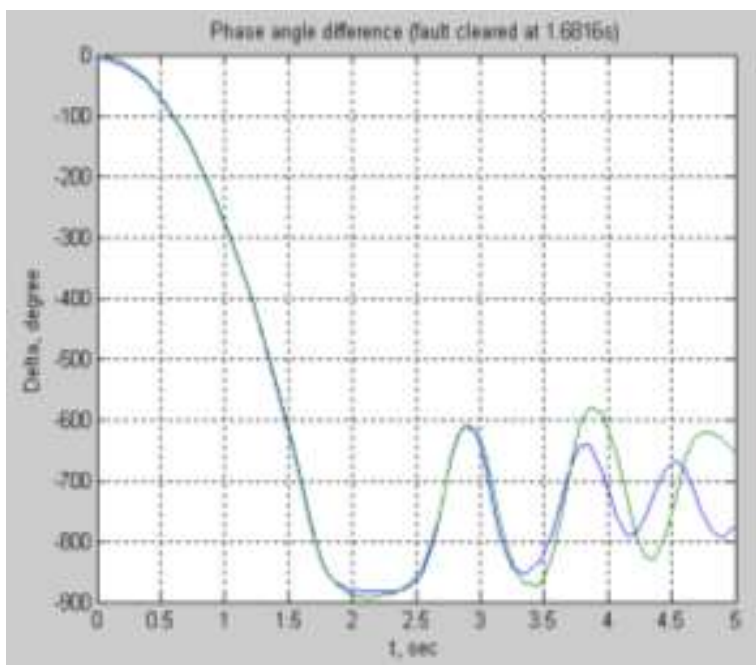

Gambar 4 Pemutusan kritis pada line 2_6 dekat bus 2 ( fault cleared at $1,6816 \mathrm{sec}$ )

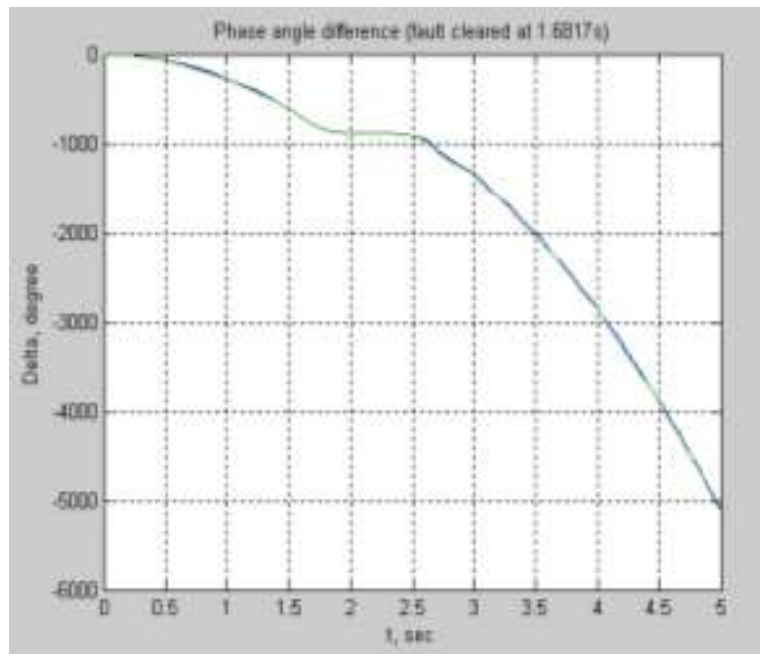

Gambar 5 Gangguan pada line 2_6 (fault cleared at $1,6817 \mathrm{sec}$ )

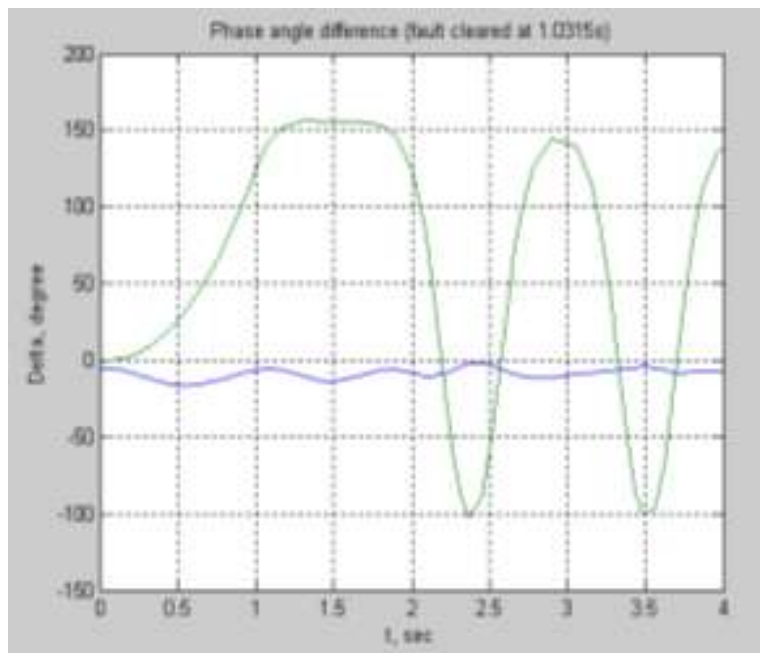

Gambar 6 Pemutusan kritis pada line 7_8 dekat bus 7 (fault cleared at $1,0315 \mathrm{sec}$ ) 


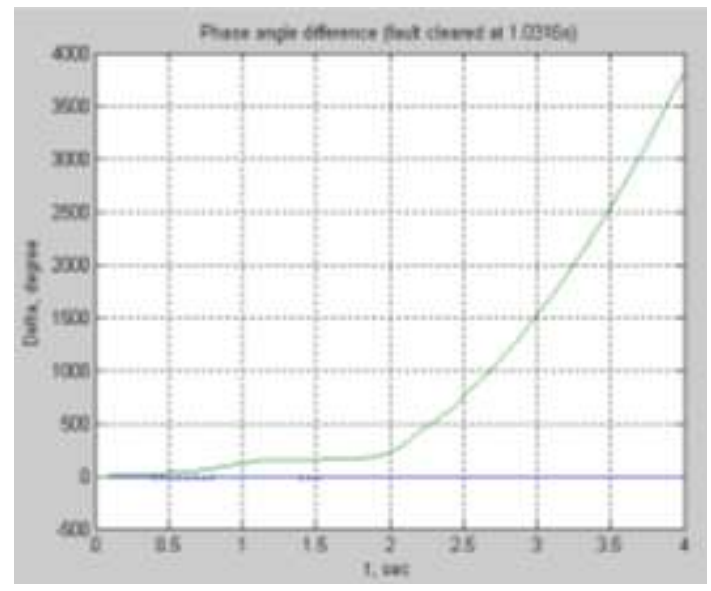

Gambar 7 Gangguan pada line 7_8 (fault cleared at 1,0316 sec)

\section{KESIMPULAN}

1. Jika terjadi gangguan dimana arus gangguan $\left(I_{f}\right)$ lebih besar daripada arus nilai pick up relay $\left(I_{p}\right)$ dan waktu bekerjanya relay harus distel / diset sedemikian rupa sehingga tidak melampaui critical clearing time (waktu pemutusan kritis) agar kestabilan mesin dalam sistem daya tetap terjaga. Jadi relay bekerja untuk memutuskan saluran yang mengalami gangguan umumnya ditentukan oleh $\left|I_{f}\right|>\left|I_{p}\right|$ dan juga oleh settingan waktu relay untuk bekerja, dimana penentuan waktu mula-mula bekerjanya relay harus lebih kecil daripada waktu pemutusan kritis saat terjadi gangguan yang umumnya diperoleh dari hasil simulasi gangguan

2. Stabilitas suatu sistem tenaga listrik adalah kemampuan dari sistem itu untuk kembali bekerja secara normal setelah mengalami suatu gangguan. Sebaliknya ketidak stabilan suatu sistem adalah kehilangan sinkron dari sistem itu.Jadi masalah stabilitas terkait dengan penilaian mesin sinkron setelah gangguan. Untuk keperluan analisis, masalah stabilitas secara umum ada dua kategori utama yaitu stabilitas steady state dan stabilitas transient. Stabilitas stady state dipandang sebagai kemampuan dari sistem tenaga untuk memperoleh kembali kesinkronan setelah terjadi gangguan kecil. Stabilitas transient dipandang pada gangguan yang mendadak sepert halnya pemutusan saluran yang mendadak, penambahan beban yang mendadak, atau perubahan beban.

3. Ada dua faktor yang dapat berfungsi sebagai kriteria petunjuk bagi kestabilan relatif suatu unit pembangkit di dalam sistem daya. Faktor itu ialah swing atau ayunan sudut mesin selama dan setelah terjadinya gangguan dan waktu pemutusan kritis. Dari swing equation (persamaan ayunan) mesin sinkron terlihat bahwa konstanta $H$ dan reaktansi peralihan $X^{\prime} d$ dari unit pembangkit (mesin sinkron) mempunyai pengaruh langsung pada kedua kriteria yang dimaksud. Makin kecil konstanta $H$, maka makin besarlah ayunan sudut mesin sinkron pada setiap interval waktu. Sebaliknya $P_{\text {maks }}$ mengecil jika reaktansi peralihan mesin sinkron $\left(X^{\prime} d\right)$ meningkat. Jadi setiap perkembangan yang memperkecil konstanta $H$ dan memperbesar reaktansi peralihan $\left(X^{\prime} d\right)$ mesin sinkron maka akan mengurangi/menurunkan kemungkinan pemeliharaan kestabilan mesin sinkron pembangkit tenaga listrik pada keadaan stabilitas transient.

\section{DAFTAR PUSTAKA}

Edminister,J.A. 1972. Theory and Problem of Electric Circuit. McGraw-Hill.

Grainger, J.J., Stevenson, D. William JR. 1994. Power System Analysis. McGraw-Hill,

Murty,P S R. 1984. Power System Operation and Control. McGraw-Hill Publishing Company Limited, New Delhi.

Nadjamuddin H. 2012. Perancangan Pembangkit Tenaga Listrik, Membumi Publishing, Makassar.

Saadat, H. 1999. Power System Analysis. McGraw-Hill.

Wood, A.J., B.F. Wollendberg. 1984. Power Generation Operation and Control, John Wiley \& Sons. 
Lampiran : Program Matlab untuk menentukan dan mensimulasikan waktu pemutusan kritis.

\begin{tabular}{|c|c|c|c|c|c|c|c|c|c|c|}
\hline $\begin{array}{c}\text { basemva }= \\
\%\end{array}$ & & $\begin{array}{l}0 \text {; accur } \\
\text { de mag }\end{array}$ & $\begin{array}{l}\text { acy } \\
\text { deg }\end{array}$ & $\begin{array}{l}=0.0001 \\
\text { loadMW }\end{array}$ & $\begin{array}{l}\text { 1; maxit } \\
\text { LdMV }\end{array}$ & $\begin{array}{l}\mathrm{r}=10 ; \\
\mathrm{Ar} \mathrm{Pm}\end{array}$ & & & & \\
\hline busdata $=[1$ & & 11.040 & 0.0 & 00.00 & 00.00 & 0.00 & 00.00 & 0 & 0 & 0 \\
\hline & 2 & $\begin{array}{ll}0 & 1.0\end{array}$ & 0.0 & 00.00 & 00.00 & 0.00 & 00.00 & 0 & 0 & 0 \\
\hline & 3 & $\begin{array}{ll}0 & 1.0\end{array}$ & 0.0 & 150.00 & 120.00 & 0.00 & 00.00 & 0 & 0 & 0 \\
\hline & 4 & $\begin{array}{ll}0 & 1.0\end{array}$ & 0.0 & 0.00 & 0.00 & 0.00 & 00.00 & 0 & 0 & 0 \\
\hline & 5 & $\begin{array}{ll}0 & 1.0\end{array}$ & & 120.00 & 60.00 & 0.00 & 00.00 & 0 & 0 & 0 \\
\hline & 6 & $\begin{array}{ll}0 & 1.0\end{array}$ & 0.0 & 140.00 & 90.00 & 0.00 & 00.00 & 0 & 0 & 0 \\
\hline & 7 & $\begin{array}{ll}0 & 1.0\end{array}$ & 0.0 & 00.00 & 00.00 & 0.00 & 00.00 & 0 & 0 & 0 \\
\hline & 8 & $\begin{array}{ll}0 & 1.0\end{array}$ & & 110.00 & 90.00 & 0.00 & 00.00 & 0 & 0 & 0 \\
\hline & 9 & $\begin{array}{ll}0 & 1.0\end{array}$ & 0.0 & 80.00 & 50.00 & 0.00 & 00.00 & 0 & 0 & 0 \\
\hline & 10 & 21.035 & 50.0 & 0.00 & 0.00 & 200.00 & 00.00 & 0 & 180 & 0 \\
\hline & 11 & 21.030 & & 0.00 & 0.00 & 160.00 & 00.00 & 0 & 120 & $0]$; \\
\hline
\end{tabular}

linedata $=\left[\begin{array}{llllll}1 & 2 & 0.000 & 0.006 & 0.0000 & 1.0 \\ 2 & 3 & 0.008 & 0.030 & 0.0040 & 1.0 \\ 2 & 5 & 0.004 & 0.015 & 0.0020 & 1.0 \\ 2 & 6 & 0.012 & 0.045 & 0.0050 & 1.0 \\ 3 & 4 & 0.010 & 0.040 & 0.0050 & 1.0 \\ 3 & 6 & 0.004 & 0.040 & 0.0050 & 1.0 \\ 4 & 6 & 0.015 & 0.060 & 0.0080 & 1.0 \\ 4 & 9 & 0.018 & 0.070 & 0.0090 & 1.0 \\ 4 & 10 & 0.000 & 0.008 & 0.0000 & 1.0 \\ 5 & 7 & 0.005 & 0.043 & 0.0030 & 1.0 \\ 6 & 8 & 0.006 & 0.048 & 0.0000 & 1.0 \\ 7 & 8 & 0.006 & 0.035 & 0.0040 & 1.0 \\ 7 & 11 & 0.000 & 0.010 & 0.0000 & 1.0 \\ 8 & 9 & 0.005 & 0.048 & 0.0000 & 1.0\end{array}\right] ;$

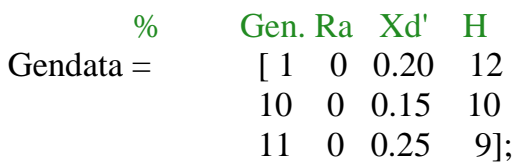

global Pm $\mathrm{fHE}$ Y th ngg

$\mathrm{f}=60$;

\%zdd=gendata(:,2)+j*gendata(:,3);

ngr=gendata $(:, 1)$;

$\% \mathrm{H}=$ gendata $(:, 4)$;

ngg=length $($ gendata(::1));

$\% \%$

for $\mathrm{k}=1$ :ngg

$\mathrm{zdd}(\operatorname{ngr}(\mathrm{k}))=\operatorname{gendata}(\mathrm{k}, 2)+\mathrm{j} * \operatorname{gendata}(\mathrm{k}, 3)$;

$\% \mathrm{H}(\mathrm{ngr}(\mathrm{k}))=$ gendata $(\mathrm{k}, 4)$;

$\mathrm{H}(\mathrm{k})=$ gendata $(\mathrm{k}, 4)$;

end

$\% \%$

for $\mathrm{k}=1$ :ngg

$\mathrm{I}=\operatorname{conj}(\mathrm{S}(\mathrm{ngr}(\mathrm{k}))) / \operatorname{conj}(\mathrm{V}(\mathrm{ngr}(\mathrm{k})))$;

$\% \mathrm{Ep}(\operatorname{ngr}(\mathrm{k}))=\mathrm{V}(\operatorname{ngr}(\mathrm{k}))+\mathrm{zdd}(\operatorname{ngr}(\mathrm{k})) * \mathrm{I} ;$

$\% \operatorname{Pm}(\operatorname{ngr}(\mathrm{k}))=\operatorname{real}(\mathrm{S}(\operatorname{ngr}(\mathrm{k})))$;

$\mathrm{Ep}(\mathrm{k})=\mathrm{V}(\operatorname{ngr}(\mathrm{k}))+\mathrm{zdd}(\operatorname{ngr}(\mathrm{k})) * \mathrm{I} ;$

$\operatorname{Pm}(\mathrm{k})=\operatorname{real}(\mathrm{S}(\mathrm{ngr}(\mathrm{k})))$;

end

$\mathrm{E}=\mathrm{abs}(\mathrm{Ep}) ; \mathrm{d} 0=\operatorname{angle}(\mathrm{Ep})$;

for $\mathrm{k}=1$ :ngg

$\mathrm{nl}(\mathrm{nbr}+\mathrm{k})=$ nbus $+\mathrm{k}$;

$\operatorname{nr}(\mathrm{nbr}+\mathrm{k})=\operatorname{gendata}(\mathrm{k}, 1)$;

$\% \mathrm{R}(\mathrm{nbr}+\mathrm{k})=$ gendata $(\mathrm{k}, 2)$; 


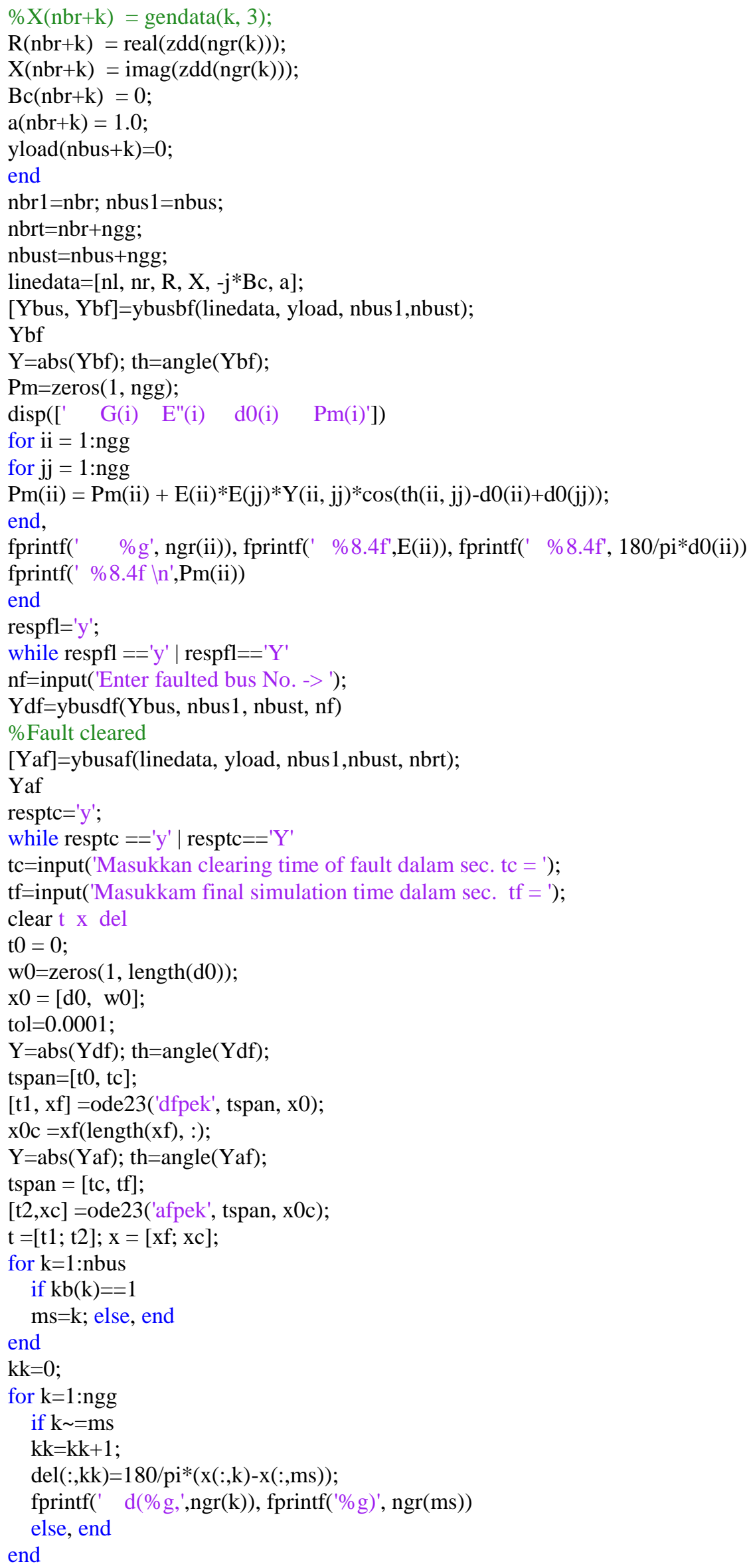

